\title{
Party cohesion in the Icelandic Althingi
}

Gunnar Helgi Kristinsson ${ }^{1}$ professor in political science, University of Iceland

\begin{abstract}
Institutional theories of party cohesion may be divided into "nomination theories" and "structure of the executive theories". The former seek explanations of cohesion in the way nominations are conducted, predicting that de-centralized and inclusive nominations will reduce party cohesion. The latter attempt to explain cohesion by reference to the structure of the executive, and predict that parliamentary government will increase cohesion.

Party cohesion in the Icelandic Althingi has, hitherto, not been extensively studied. In this article, large amounts of data are explored to test hypotheses derived from the two theoretical approaches. The analysis is based on roll-call data dating back to 1961 and electronic voting records from 1991 onwards. The main conclusion is that party cohesion is at a high level in Iceland, despite decentralized and inclusive nominations, and hypotheses derived from nomination theories therefore find no support in our data. Hypotheses derived from "structure of the executive theories" fare much better and the main reason for high party cohesion in Iceland seems to be parliamentary government. Various features of our data, however, encourage us not to ignore other contextual features affecting party cohesion, which neither of the two institutional theories can account for satisfactorily.
\end{abstract}

\section{Keywords}

Party cohesion, political parties, nominations, parliamentary government

Parties dominate legislatures to such an extent that it has almost ceased to cause wonder. The emergence of disciplined parliamentary groups in nineteenth-century England, according to Cox (1987), went hand in hand with a more party-oriented electorate which gave the cabinet a key position when dealing with parliament. Other studies (e.g. Kam 2009) find a corresponding effect in the way partisan de-alignment among voters in recent decades has increasingly tempted parliamentarians to act independently of their party groups. But the surprising thing, despite decades of electoral 
de-alignment (cf. Crewe \& Särlvik 1983), is the degree to which members of parliament still tend to conform to the joint decisions and discipline of the respective party groups.

Why a less partisan electorate has not led to greater loss of party cohesion in parliament may have different explanations. For one thing it seems possible that the measurements traditionally used for party cohesion are not sensitive enough to capture the trends, the most common one being the Rice index. An alternative possibility, suggested by Kam (2009), is that the use of additional instruments to enforce cohesion may offset the pressures caused by de-alignment to some extent.

Party cohesion is defined as "the extent to which, in a given situation, group members can be observed to work together" (Ozbudun 1970, 305). The definition is neutral with regard to why groups work together and avoid splits, e.g. if cohesion is maintained because of genuine agreement on policies or the use of party discipline. In actual research situation a behavioural definition is preferable to a definition based on values or motives, which may be difficult to establish. A variety of indicators may be used to reflect party cohesion (Bowler, Farrell \& Katz (eds.) 1999; Hazan (ed.) 2006). It may, for example, be studied though qualitative methods, including analyses of the contents of bills, resolutions or speeches. Similarly, conclusions may be drawn from data such as the number of private members' bills, government defeats, roll-call votes and party switching. It is also possible to use interviews and questionnaires, e.g. among parliamentarians.

Studies of party cohesion are usually confined to parliamentary party groups, although strictly speaking they need not be. In the present study we follow tradition in this respect and operationalize party cohesion as the degree to which members - for whatever reason - vote the same way. The main advantages of studying party cohesion through parliamentary voting are partly the directness of measurement and partly the availability of data in many countries, for different parties over longer periods of time.

To account for the importance of parties in parliamentary voting, attention must be paid to both the individual motives and incentives which affect the behaviour of parliamentarians and the institutional or organizational factors which influence them. We start with a short consideration of the individual level and then move on to institutional factors, which are the main subject of the present study.

\section{Incentives for team playing}

To bring about some minimum of consistency and cohesion among groups of parliamentarians, above what spontaneous opinion making provides, incentives for compliance must exist. Such incentives fall into two broad categories, i.e. access to influence and career-related considerations.

For policy-concerned parliamentarians, as Bowler (2000) points out, belonging to a party has procedural and policy advantages. Being part of a group of parliamentarians is likely to give members access to greater policy influence than they could generally obtain individually. This may result from log-rolling in the majority, party or government control of the agenda, and access to committee places and ministerial posts in parliamentary systems. Group membership, however, usually makes demands 
on the willingness to compromise. All but the most homogenous of parties must depend on some degree of log-rolling among their parliamentarians which means that members must in some cases support proposals which go against their convictions if they wish to secure the long run benefits of belonging to the group. They need to solve collective action problems through organizational means and enforce commitment over a range of issues for an extended period of time whereby each member votes not only according to his or her tastes but also to maintain the collective benefit (e.g. a workable majority).

Career-related considerations play a role when the parties control values of personal interest to individual members, not least of which is power over nominations (e.g. Bowler, Farrell \& Katz eds. 1999). Other career prospects may play a role as well. Promotion comes in various forms in parliamentary systems but is usually controlled by the party leadership. The positions which parliamentarians may aspire for include valued committee places, committee chairs, "whips", junior minister posts, cabinet posts and various positions in the executive controlled by the parties. Finally, the desire for security may affect the willingness of MPs to act in a cohesive manner. Among the tools available to prime ministers in parliamentary systems for calling government supporters to order is the threat of dissolving parliament and calling a new election, which for MPs may create the risk of not being re-elected, in addition to entailing potentially costly nomination and election campaigns. Given the insecurity of a political career, moreover, the desire for patronage in a future post-parliamentary existence may tempt MPs towards compliance rather than revolt, if the goodwill of the leadership has anything to do with such benefits.

\section{Control over legislatures}

Creating cohesive groups out of different opinions in parliament requires organizations or institutions with the means and motives to enforce cohesion. Party organization is one such; the cabinet, in parliamentary systems, is another.

\section{Control by party organization}

Among the most frequently studied mechanisms used by parties to keep parliamentarians in check is party control over nominations, based on the assumption that members seek re-relection (e.g. Bowler, Farrell \& Katz eds. 1999). Nomination theories of party cohesion predict that greater institutionalization of selection processes within the parties will lead to greater cohesion in the parliamentary party groups.

According to Panebianco $(1988,18)$ institutionalization leads to organizational stability, stable survival interests and stable organizational loyalties The institutionalization of party organizations takes the form of autonomy, on the one hand, and "systemness", on the other. Autonomy means that the party has clearly organized boundaries, including a clear understanding of who belongs to it and where it leaves off. It can refer to a range of factors which reduce the dependence of party organizations on their environment, including party finance, membership structure and nominations. An endogenously financed party, with a clear framework for membership rights and duties 
and a closed, non-inclusive system of nominations, may be considered relatively autonomous compared to an organization where these characteristics do not apply. Such an organization is also likely to demand organizational loyalty from its representatives.

Systemness, the other main ingredient of institutionalisation, implies "a great deal of interdependency among the sub-groups assured by the centralized control of organizational resources" (Panebianco 1988, 56). Centralization is an important indicator of "systemness" in party structure. In the context of nominations, decentralization refers to the importance of local principals as opposed to more central ones in winning support for re-selection. According to Bowler et al. (1999) "local party organizations and caucuses can be quite disruptive" and "local nomination means not only that legislators have a local base from which to oppose strong leaders but also that they face local demands that may lead to dissent" (p. 8).

The relationship of institutionalization to party cohesion according to nomination theory is displayed schematically in Table 1.

Table 1. Institutionalization, candidate selection and party cohesion according to nomination theor

\begin{tabular}{|c|c|c|}
\hline Institutionalization of & Corresponding methods & $\begin{array}{l}\text { Hypothesized effects on } \\
\text { cohesion: }\end{array}$ \\
\hline refers to: & the & \\
\hline Autonomy & Less inclusive methods & $\begin{array}{l}\text { Less inclusive methods } \\
\text { increase cohesion }\end{array}$ \\
\hline Systemness & $\begin{array}{l}\text { Centralised selection } \\
\text { methods }\end{array}$ & $\begin{array}{l}\text { Centralization increases } \\
\text { cohesion }\end{array}$ \\
\hline
\end{tabular}

\section{Control by the executive}

Parliamentary government is characterized by a relatively large degree of control over the legislature by the executive. The most important instruments of control are the party groups. Parliamentary government is likely to increase the role of parties in parliamentary voting and encourage greater cohesion than presidential systems (Ozbudun 1970; Owens 2006). We call this the structure of the executive theory. Parliamentary government is fundamentally party government, where access to collective and selective goods goes through parties and often depends on belonging to the parliamentary majority. Studying the impact of parliamentary government and party organization on cohesion poses a problem, however, in that the two are likely to be interrelated as well as related to party cohesion. "[P]arliament-dependent government" as Sartori (1994, p. 193) puts it "implies party-supported government; a support that in turn requires voting discipline along party lines".

In a parliamentary system, a government which is unable to demonstrate sufficient 
support in parliament must fall. The level of tolerance for defections varies (Beyme 2000). In some cases the defeat of an important government bill may signal the end for a government. But even when government bills scrape through, significant defections on the government side are considered a serious weakness. Hence, leaders of the government have a powerful incentive to secure cohesion in the government as a whole and each of the government party groups where coalition governments prevail. They therefore devote a lot of time and effort to convincing their followers, who also sometimes acquire an opportunity to influence policy. The question is what expectations we should have with regard to parties in the minority. Some of the features of parliamentary government may promote cohesion in the minority parties because they have strong incentives to project themselves as credible government alternatives, evaluated according to their ability to present a cohesive front. But since the opposition does not have to pass the same tests of support as the government, the pressure for cohesion in the opposition is weaker.

In most parliamentary systems, rules of procedure in the legislature are biased in favour of the government majority (Döring 1995). This may help efforts by government leaders to maintain cohesion in their ranks and apply divide-and-rule tactics vis-à-vis the opposition. A government with strong control of the parliamentary agenda can, to a certain extent, determine which issues are put to a vote. While not too much appears to be known about how governments use their control over the work of parliament, governments seem likely to select issues which maximize cohesion within their own ranks while neutralizing the opposition. The opposition parties, on the other hand, stand a better chance of promoting issues which unite them where government control of the agenda is weaker.

\section{Party cohesion in the Icelandic Althingi}

So far, we have discussed the potential impact of two major factors on party cohesion in parliamentary voting. One is the desire by party organizations to control representatives (nomination theory) and the other the desire by the cabinet in parliamentary systems to control them (structure of the executive theory). In the case of party organizations, institutionalization through autonomy and systemness has been spotted as a potential factor increasing cohesion. In the case of the cabinet, the need of the government to demonstrate sufficient support in parliament, and its control over parliamentary procedure or agenda, may have the same effect. In this section we apply this framework to the Icelandic case, and develop testable hypotheses relevant to the preceding discussion.

Political parties in Iceland are formally mass membership organizations reporting proportionally higher membership figures than are found in other mature democratic states (Kristinsson 2010). The figures published by the parties amount to $42 \%$ of the electorate, while self-reported membership in opinion polls yields a far lower figure (27\%) but still a very high one in a comparative perspective (cf. Whiteley 2011). Research indicates that the main reason for these unique figures has more to do with the way nominations are conducted than a high level of party activism.

All the Icelandic parties practice decentralized nominations where the composition of party lists is essentially up to the constituency-level party organizations. Although 
the election law offers voters certain scope for ranking candidates on their ballot papers, or deleting them, in parliamentary elections, this in practice never affects who is actually elected, leaving effective choice to the parties. Since about 1970, the parties have experimented in various ways with making the nomination process more inclusive than before by using primary elections to the party lists (Kristjánsson 1994). In the period 1971-1991, studied by Kristjánsson, three of the four major parties held highly inclusive primaries: the conservative Independence Party, the Progressive Party (centre - formerly a farmers' party) and the Social Democrats. The party farthest to the left, the People's Alliance, used much less inclusive nomination methods. In recent years, the Independence Party, and to a lesser extent the Social Democrats, have held on to inclusive nominations, while they have become less inclusive in the Progressive Party. In the Left Greens (who took over from the People's Alliance as the party farthest to the left in 1999) the nomination process remains less inclusive than in the other parties, but trends towards greater inclusiveness may be observed in 2007 and 2009.

Conduct of the primaries varies not only between parties, but also within them. In some cases, nominations are open to all self-proclaimed party supporters, but more often in recent years they have been open to party members and those who have filed an application for membership. Such requirements do not appear to deter voters and it is, in fact, not uncommon for voters to be registered members in more than one party. Since membership makes no demands as to financial or other contributions to the party, those who have once registered tend to remain registered. Thus, large membership figures in the Icelandic parties actually reflect a reality of weak party organizations, where the activists have been "defanged" in a decentralized and highly inclusive system of nominations (Kristinsson 2010).

Rahat and Hazan (2001, p. 301) order selectorates in party nominations from greater inclusiveness (as in American style open primaries) stepwise towards greater exclusiveness through selection by party members, selected party agency, non-selected party agency or party leader. Democratizing the selection process through greater inclusiveness, they maintain, may enable candidates to circumvent the party leadership and appeal directly to party members and voters at large. This could lead to "a drastic weakening of partisan discipline and cohesiveness, leading to a decline in the ability of the parties to function as a stable basis for the political process and to operate effectively in the parliamentary arena" (pp. 312-3).

According to Kristjánsson (2003) the primaries in Iceland have undermined control by the parties of individual parliamentarians.

The gradual transformation of the Icelandic political system, from party rule to personal politics, is ... manifested at the parliamentary party group level. The MPs have gained more freedom of action; they are agents without any strong party organization to control them. Members of Parliament have extended their freedom of action into new areas, including decisions about whether to support or oppose the cabinet in the Althingi (p. 405).

In line with this argument we may present a hypothesis of low party cohesion in parliament.

H1. The primaries have the effect of producing smaller party cohesion in the 
Icelandic parliamentary party groups than in neighbouring states where nominations are less inclusive.

The other major aspect of institutionalization, systemness, is less fruitful in producing testable hypotheses in the Icelandic context. All the parties have a long tradition of decentralized nominations, which might lead us to expect a low level of cohesion, but since we have no meaningful variations in this variable it is not suitable for testing in the present context. Predicting the level of cohesion in a comparative perspective, however, we should expect it to be relatively low compared to countries with more centralized nomination procedures.

Given the varying degrees to which the parties have adopted inclusive nomination procedures we should expect corresponding variations in their degree of cohesion.

H2. Parties with more inclusive nomination procedures should be characterized by smaller cohesion at the parliamentary party group level than parties with less inclusive ones.

Furthermore, since the primaries started around 1970 and became established during the 1970s, we should expect a clear break during the 1970s with the previous level of cohesion in the parties adopting them.

H3. A sharp decline should be evident in cohesion in the parties adopting primaries during the 1970s, resulting in a lower level of party cohesion than before.

Iceland is a parliamentary democracy where majority coalitions are the norm and minority governments serve only on a provisional basis. Parliamentary government and the prevalence of majority coalitions should contribute to a high degree of party cohesion.

H4. Parliamentary government and majority coalitions should lead to a high degree of party cohesion in Iceland. Cohesion in the parties, moreover, should be greater in government than in opposition.

$\mathrm{H} 4$ is party antithetical to $\mathrm{H} 1$, above, in that whereas $\mathrm{H} 1$ predicts smaller party cohesion than in neighbouring states, $\mathrm{H} 4$ predicts party cohesion at a similar level to neighbouring states with a similar form of government.

The Icelandic parliament, the Althingi, has worked in a single chamber since 1991 and is, according to Arter (2000), a relatively influential parliament where members enjoy liberal rights. There are virtually no restrictions on the right of individual members to propose legislative bills or other resolutions. During the early twentieth century, private members' bills stood a fair chance of becoming legislation, although - as Magnússon $(2011,366-8)$ points out - they were often prepared in cooperation with the government. Time limits on speeches are not strict, even if they have been tightened somewhat and filibustering tactics, or the threat of using them, are sometimes employed by the opposition to force the government to negotiate.

According to Döring (1995), government control of the agenda in Iceland is similar to that in Denmark, Finland and Sweden. It is smaller than in the majority of western European states, but greater than in Italy and the Netherlands (p. 225). Important 
aspects of agenda control in the Althingi, nonetheless, remain firmly in government hands, and its position may be even stronger than suggested by Döring. All bills, as a rule, are referred to standing committees, chaired by members of the parliamentary majority, often (but not always) from the same party as the relevant minister. The standard method of killing bills is not to deny them access to a committee but to bury them in the committees, a method which, according to Mattson (1995), is also frequently used in Austria, Belgium, Denmark, Luxembourg and Portugal (p. 465).

Table 2. Fate of legislative bills in the Althingi 1999-

\begin{tabular}{|l|r|rr|}
\hline Type of bill & Number of bills & \multicolumn{2}{|l|}{ \% put to a vote } \\
Government bills & 1,177 & & $85.0 \%$ \\
Committee bills & 66 & & $90.9 \%$ \\
$\begin{array}{l}\text { Private members' bills: } \\
\text { Government MPs }\end{array}$ & 190 & & $12.6 \%$ \\
$\begin{array}{l}\text { Private members' bills: } \\
\text { Opposition MPs }\end{array}$ & 555 & & $1.1 \%$ \\
\hline
\end{tabular}

Source: Annual reports of the Althingi (Ársskýslur Alpingis), relevant years.

Thus, although the members of the Althingi enjoy liberal rights to propose new legislation, only the government - sometimes working through the committees - has a good chance of having them put to a vote. Sometimes ministers introduce bills for the purpose of "airing" them late in the session, while not aiming at final passage until later. But most government bills survive the committee stage. Private members' bills, however, have a slim chance of emerging out of the committees, and the chances of opposition members' bills are negligible. Moreover, what little chance there exists $(1.1 \%)$ is limited to non-controversial issues. Five of the six opposition bills that came to a vote in 1999-2008 were passed without opposition in the chamber and none was defeated.

It seems likely that if the government majority can prevent voting on controversial minority bills, by killing them in committee rather than in plenum, this may favour cohesion in the government parties and harm it in the opposition.

H5. Strong control by the government of the parliamentary agenda should increase party cohesion in the government and reduce it in the opposition.

\section{Measurement}

A standard measure of party cohesion is the Rice index, first described by Stuart A. Rice (1925) and subsequently adopted by many others (e.g. Ozbudun 1970; Rahat 
2007). According to Rice, full cohesion (100.0) is obtained when all members vote the same way, while no cohesion (0.0) reflects a situation where they are divided into two equally large groups, for and against a proposal. The points in between are determined by the degree to which members depart from the full 50-50 split (i.e. 0.0 cohesion) towards greater unity ${ }^{2}$. The Rice index can be calculated for a single voting procedure, and a mean may also be calculated for a series of votes to indicate the overall level of cohesion for a group (such as a parliamentary party) over a given period of time.

The Rice index may be interpreted as an indicator of the frequency with which party members vote against each other. Among its attractive features is simplicity. Abstentions, however, can pose a problem. Abstentions are simply treated as missing values. Where abstentions are common they may cause problems of interpretation, e.g. if only a minority of members actually takes part in the vote, let alone if they all abstain (in which case an index cannot be calculated). To deal with abstentions, an index of agreement may be calculated (e.g. Davidson-Schmich 2006) by adding the minority position in the party to abstentions and subtracting these from the majority votes $^{3}$. As in the non-modified Rice index a fifty-fifty split between the majority and the combined minority and abstentions will give 0.0 and full unity 100.0. Calculating the index in this manner is sensitive to the kind of dissension manifested by the more moderate step of abstaining rather than voting against the majority position. It is theoretically possible that the minority votes and abstentions will outnumber the majority (e.g. in the case of many abstentions), in which case the index will produce a negative outcome, approaching -100.0 in severe cases. But according to this method, abstentions are treated as an indication of disunity, even if the whole party were to abstain. A more logical solution is that of Attinà (1990) who treats yes, no, and abstentions as three different alternatives which members are faced with in elections, each of which may be the majority (or plurality) position. ${ }^{4}$ In this case the 0.0 outcome would reflect a situation where the plurality equals the combined share of both minority positions while -33.3 would reflect a split into three equal camps $(33.3 \%$, $33.3 \%$ and $33.3 \%$ ). The problem with Attinà's solution is that negative outcomes become possible. Hence Hix, Noury and Roland $(2005,215)$ suggest a formula which projects Attinà's solution on a scale from $0.0-100.0^{5}$. In the following we shall be using this measure for party cohesion unless otherwise noted. Correlation ( $r$ ) between this index and Attinà's index is of course 1.00 while the two have a .54 correlation to the unmodified Rice index in our data. ${ }^{6}$

\section{Data}

Voting in the Icelandic Althingi has not been extensively analysed before, although Jensen (2000) calculates a cohesion index for final votes on legislative bills during one session in 1995-96. Our data includes all voting in the Althingi from October 1991 (when electronic voting was introduced) until 2010. Raw voting data was obtained from the Althingi's office, based on electronic records and analysed with specially designed software.

A significant number of decisions in parliaments are made unanimously or near unanimously (Loewenberg \& Patterson 1979, pp. 225-6), e.g. where voting takes place 
for procedural reasons rather than to test the majority will. Some issues are also primarily technical and can be resolved without disagreement, while other may be the result of compromise or consensus building. This may lead to flawed cohesion indexes, e.g. where all members of all parties vote the same way, yielding cohesion scores of 100 for each party, while a plausible explanation for the result might be that parliament was working in a non-party or unanimity mode.

There are several ways to by-pass this problem. One is to study only final voting on bills. Although quite a number of bills are also passed unanimously, the problems of interpreting procedural votes is avoided by confining the analysis to final voting on bills. These are, in all cases, substantive political decisions. However, if we wish to confine the analysis to bills where there is some minimum amount of disagreement, it may in some cases make sense to study only "disagreement issues", i.e. issues where there is at least one vote which goes against the parliamentary majority. ${ }^{7}$

Yet another way around the problem of inflated cohesion scores due to non-party or unanimity vote is to study only roll calls. Roll calls are special votes occasionally called for to make the way each member votes a matter of public record. Many analyses of party cohesion depend on roll-call votes which are more commonly available than the full voting record. The question is, as Hug (2009) points out, if roll calls are really representative of the voting which takes place. Saalfeld (1995) suggests that roll calls enhance party unity by making the voting behaviour of members more public and hence observable, e.g. to party whips.

The procedure for roll calls in Iceland is liberal in the sense that any member can demand a roll call according to the Althingi's standing orders and the speaker is obliged to comply. No data exists showing the identity of those who have demanded roll calls in Iceland, but the purpose of the move is usually to embarrass the opposite side. The presence of disagreement may thus usually be assumed in roll calls in the Icelandic parliament. The roll-call data is limited in two respects, however. On the one hand there is no data for the period 1988-91 on account of what appears to be a failure to include votes in the electronic records. ${ }^{8}$ On the other hand, meaningful roll-call data is available only for the period 1961-91. Older records do not exist in electronic format and after 1991 - when electronic voting was introduced - the roll-call procedure lost most of its former significance since the way individual parliamentarians voted became a matter of public record in any case. Roll calls have been much less frequent since 1991, although they can still take place in accordance with the standing orders. 


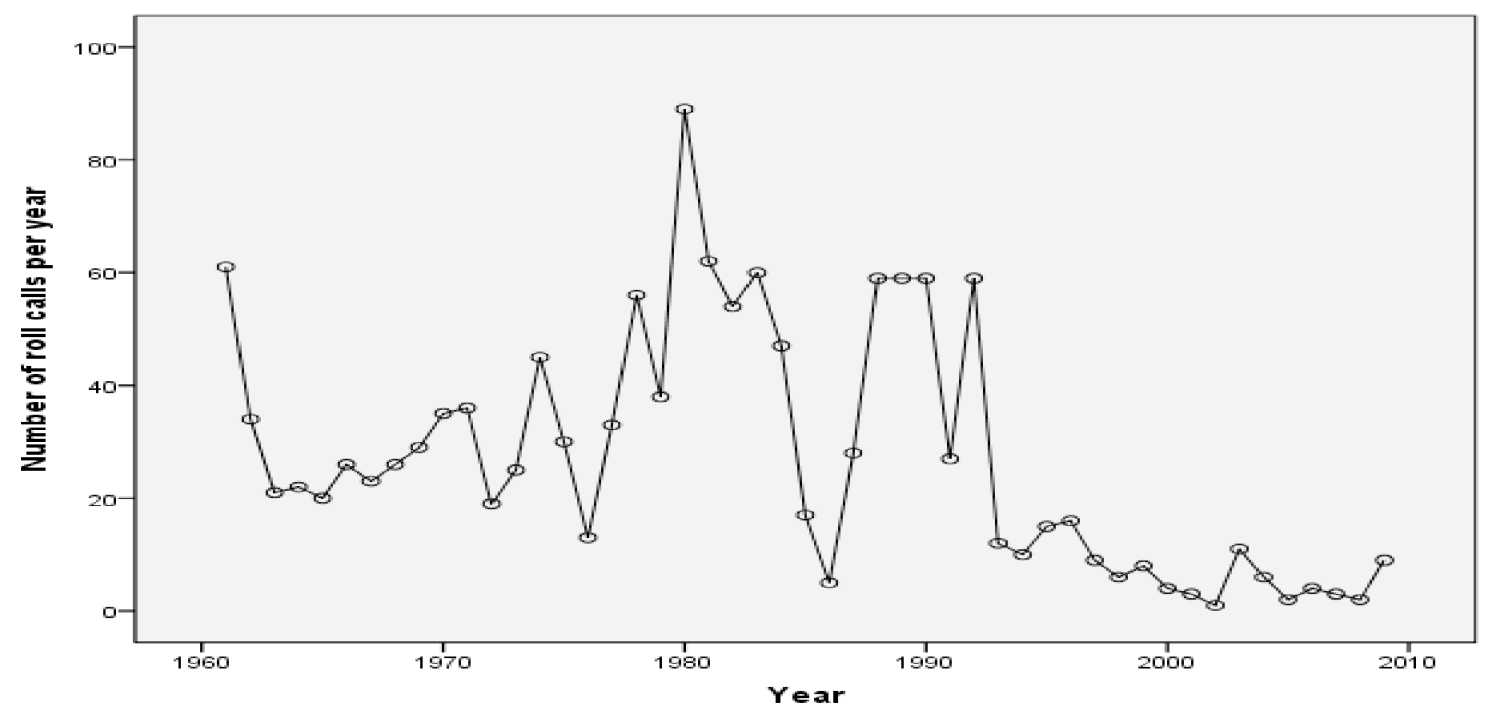

Note: The three years 1988-91 are estimates calculated on the basis of figures given by Saalfield (1995, 539). The number of roll calls in 1961-87 is slightly underestimated since texts with typographic or similar errors could not be included.

Graph 1. Number of roll calls in the Althingi 1961-2010

In 1961-91 the average number of roll calls per year was 38, compared to 11 since 1991. For most years after 1991 the data is too limited to provide a stable basis for analysis and hence cohesion scores are not calculated on the basis of roll-call data for this period.

Government control of the parliamentary agenda may affect measures of party cohesion in Iceland because the government effectively controls which bills come to a final vote in the Althingi. If the government can choose to vote only on bills where the government parties are united and the opposition ones divided, this may give a distorted view of the actual amount of cohesion prevailing in the different camps. But while the government effectively controls which bills survive the committee stage, it has no such control over the amendments which are proposed. Hence, by looking at the amendments separately, we may examine party cohesion that is relatively unaffected by government control over the agenda. The total number of votes included in our study of the period 1991-2010 is shown in Table 3.

Table 3. Voting in the Althingi 1991-2010: Unity and disagreement on bills and amendments (absolute numbers)

\begin{tabular}{|c|c|c|c|}
\hline & Unity issues & $\begin{array}{l}\text { Disagreement } \\
\text { issues }\end{array}$ & Total \\
\hline Final voting on bills & 1,314 & 892 & 2,206 \\
\hline Amendments & 8,432 & 10,130 & 18,562 \\
\hline Total & 9,746 & 11,022 & 20,768 \\
\hline
\end{tabular}


The data covers just over 20,000 instances of voting in the Althingi involving each of the parties which existed during the whole period. About half the votes fall into the category of unity issues and the other half are disagreement issues. The majority are votes on amendments, while $11 \%(2,206)$ are final votes on bills.

\section{Results}

\subsection{Comparisons with other parliamentary democracies (H1)}

According to $\mathrm{H} 1$, we should expect a relatively low level of cohesion in Icelandic parliamentary parties on account of a personalised selection process. The right to participate in nominations is confined to party members in most parliamentary democracies, as Narud (2008) points out, and usually only a fraction of them participate.

Table 4. Inclusiveness and decentralization in Northern European parliamentary selection processes

\begin{tabular}{|l|l|l|l|}
\hline Centralization: & $\begin{array}{l}\text { Inclusiveness: } \\
\text { Open primaries }\end{array}$ & $\begin{array}{l}\text { Selection by party } \\
\text { members }\end{array}$ & $\begin{array}{l}\text { Selection by } \\
\text { delegates }\end{array}$ \\
\hline $\begin{array}{l}\text { Decentralized } \\
\text { selection }\end{array}$ & Iceland & $\begin{array}{l}\text { Finland, Denmark, } \\
\text { Germany }\end{array}$ & Norway, Sweden \\
\hline $\begin{array}{l}\text { More centralized } \\
\text { selection }\end{array}$ & & Ireland, UK & \\
\hline
\end{tabular}

Note: In addition to involving party members, Denmark, Finland and Ireland have preferential systems which allow voters an active role in selecting individuals from the lists provided by the parties. Based on Narud (2008); Gallagher, Laver and Mair (2006); Bille (2001). More centralized selection means that candidates may require central party approval.

In general, the Nordic countries and Germany have a strong tradition of decentralized selection procedures, while the degree of inclusiveness varies between countries. Iceland has the most inclusive system, with a tradition of more or less open primaries in three of the four major parties. A system of preferential voting, where most parties also involve party members in the selection procedure for party lists, also makes the Danish and Finnish systems relatively open. Norway and Sweden, on the other hand, confine the selection procedures to party delegates, although Sweden has a procedure for preferential voting which generally has a limited impact in elections (Nielsen 2007). In Ireland and the UK, the central party leadership tends to have a greater role. The Irish STV gives voters an important role in deciding which of the party candidates is elected, but the effects of this are to some extent contained by small district magnitude.

Fully comparable data on party cohesion is hard to come by. For the Nordic countries, however, it may be assumed that Jensen's (2000) study is based on comparable data. ${ }^{9}$ Sieberer (2006) has collected additional data from secondary sources and for Ireland we add data provided by Depauw and Martin (2009). 
Party cohesion in the Icelandic Althingi

Gunnar Helgi Kristinsson

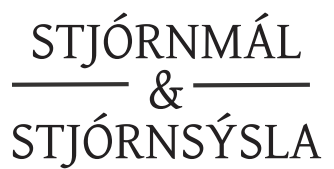

Table 5. Party cohesion in Northern Europe

$\begin{array}{lcccc}\text { Country } & \text { Period } & \begin{array}{c}\text { Number of } \\ \text { parties }\end{array} & \begin{array}{c}\text { Mean party } \\ \text { cohesion }\end{array} & \begin{array}{c}\text { Standard } \\ \text { deviation }\end{array} \\ \text { Denmark } & 1990-96 & 8 & 99.83 & 0.009 \\ \text { Finland } & 1995-96 & 7 & 88.63 & 2.59 \\ \text { Germany } & 1980-90 & 4 & 96.60 & 1.97 \\ \text { Iceland } & 1995-96 & 6 & 96.93 & 2.84 \\ \text { Ireland } & 1992-96 & 3 & 100.00 & 0.00 \\ \text { Norway } & 1990-94 & 6 & 98.72 & 0.56 \\ \text { Sweden } & 1994-95 & 7 & 96.57 & 1.51 \\ \text { UK } & 1992-97 & 2 & 99.31 & 0.22\end{array}$

Sources: Jensen (2000); Sieberer (2006); Depauw and Martin (2009).

As Table 5 indicates, party cohesion is generally high in Northern Europe and the degree of inclusiveness appears not to affect the distribution at all. The scores for party cohesion are very high where centralization is greater (Ireland and UK) but the small number of cases and small variations in cohesion do not warrant any generalization to that effect. Sieberer $(2006,163)$, however, comes to the conclusion that "average party unity is higher if the central party leadership plays a formally guaranteed role in candidate selection". Iceland, according to Table 5, is close to the mean for party cohesion in Northern Europe and, contrary to H1, in no way stands out for lower cohesion.

The data provided by Jensen (2000) on Iceland is limited in that it covers only final voting on legislative bills during one parliamentary year. Looking at the whole period 1991-2010, our results for Attinà's agreement index are 96.38 and for the cohesion index $97.29 .{ }^{10}$ The conclusion with regard to $\mathrm{H} 1$ is the same.

\subsection{Comparisons between parties ( $\mathrm{H} 2)$}

In recent elections, almost one third of Icelandic voters claim to have voted in the party primaries (Kristinsson 2010). Two of the Icelandic parties, the Independence Party and Social Democrats, have used primaries two thirds of the time since 1991. Although the formal rules often make party membership or an application for membership a precondition for participation, this does not seem to deter voters from participating, since duties associated with membership - such as membership fees - are practically non-existent. In the election of 2009, 42-67\% of Independence Party voters voted in the primaries and $15-49 \%$ of Social Democratic Alliance voters ${ }^{11}$. The Progressive Party uses a more varied menu for nominations and indications are that the inclusiveness of its nomination process is more restricted than in the former two cases. Least inclusive is the nomination process in the Left-Greens and formerly the People's Alliance. They usually prefer selection by delegates and although they have used selection by party members (in the elections of 2007 and 2009) the process was confined to a much smaller group of party members than in the other parties (Kristinsson 2010). 
According to $\mathrm{H} 2$, we should expect party cohesion to differ between the parties according to the degree of inclusiveness. More inclusive nominations should lower party cohesion.

Table 6. Mean cohesion in major parties 1991-2010

\section{Party}

Independence Party

Left Greens*

Liberal Party

Progressive Party

Social Democratic Alliance**

Women's Alliance

Note: Final votes on bills.

*People's Alliance 1991-1998

**Social Democratic Party 1991-1998

\section{Period covered}

1991-2010

1991-2010

1999-2009

1991-2010

1991-2010

1991-1998
Mean cohesion

98.95

95.53

98.08

97.88

98.92

95.80

Table 6 lends no support for the hypothesized connection between party primaries and party cohesion. On the whole the variation between the parties is small, even if they have applied different nomination methods. Moreover, the parties with the most inclusive nominations, i.e. the Independence Party and the Social Democrats, are also the most cohesive ones, contrary to what we should expect according to $\mathrm{H} 2$.

Restricting the examination to final votes on bills may exaggerate the degree of party cohesion by including consensus issues, where parties actually play a very limited role. By eliminating consensus issues we may to a certain extent control for consensus and analyse cohesion where there is some minimum amount of disagreement. This is done in Table 7 . Issues are here counted as consensus issues if no vote is cast against the majority.

Table 7. Mean cohesion in major parties 1991-2010. Disagreement issues only.

$\begin{array}{lcc}\text { Party } & \text { Period covered } & \text { Mean cohesion } \\ \text { Independence Party } & 1991-2010 & 97.56 \\ \text { Left Greens* } & 1991-2010 & 87.38 \\ \text { Liberal Party } & 1999-2009 & 94.30 \\ \text { Progressive Party } & 1991-2010 & 95.96 \\ \text { Social Democratic Alliance** } & 1991-2010 & 93.62 \\ \text { Women's Alliance } & 1991-1998 & 92.49 \\ \quad \text { *People's Alliance 1991-1998 } & & \\ \quad * * \text { Social Democratic Party 1991-1998 } & \end{array}$

Obviously the cohesion index is lower when consensus issues are excluded. It remains relatively high for all parties, nonetheless, and Table 7 lends no more support to $\mathrm{H} 2$ than did Table 6. The party with the most inclusive primaries, i.e. the Independence 
Party, is still the one with the greatest degree of cohesion, while the smallest degree of cohesion is found in the Left Greens.

\subsection{Development over time (H3)}

According to $\mathrm{H} 3$, we should expect party cohesion to decline in and after the 1970s in those parties which adopted inclusive primaries around 1970.

The extant data covering this period consists of roll-call data only. The roll-call tradition in Iceland reflects controversy and attempts to embarrass the other side rather than party whips calling their troops to order. According to Table 8 below, rollcall cohesion is lower than both final voting on bills and disagreement voting in the subsequent period. We have no means of testing the difference for the same period, however, since roll calls after the introduction of electronic voting in 1991 have lost much of their political significance and occur much more rarely than before. Roll calls are the only data, however, which we have of the crucial period 1961-87 and we may assume them to be internally consistent, and hence to provide indicators of trends, even if they may not be fully representative of all votes.

Table 8. Mean cohesion index for major parties $1961-1987$ based on roll calls

\begin{tabular}{|c|c|c|c|c|c|}
\hline Party & N (years) & Mean & $\begin{array}{c}\text { Std. } \\
\text { Deviation }\end{array}$ & $\begin{array}{l}\mathbf{r} \text { (cohes- } \\
\text { ion and } \\
\text { time) } \\
1961-87\end{array}$ & $\begin{array}{c}r \text { (cohes- } \\
\text { ion and } \\
\text { time) } \\
1961-70\end{array}$ \\
\hline Independence Party & 27 & 87.84 & 8.97 & $-.57 * *$ & $-.83 * *$ \\
\hline People's Alliance & 27 & 89.37 & 6.08 & -.13 & $-.68 *$ \\
\hline Progressive Party & 27 & 88.39 & 5.73 & .18 & -.13 \\
\hline Soc.-Democr. Union & & & & & \\
\hline (Bandalag jafnaðarmanna) & 3 & 95.95 & 3.79 & .61 & - \\
\hline Social Democratic Party & 27 & 88.81 & 9.17 & $-.54 * *$ & -.34 \\
\hline Union of Liberals and Leftists & 8 & 86.13 & 9.55 & $-.72 *$ & - \\
\hline Women's Alliance & 5 & 92.69 & 4.92 & -.46 & - \\
\hline
\end{tabular}

Looking first at the period 1961-87, we see that party cohesion is reduced significantly over time in three of the parties, i.e. the Independence Party, Union of Liberals and Leftists (ULL) and the Social Democratic Party. The ULL was a splinter group from the People's Alliance aiming at the unification of Icelandic leftists, but was soon torn apart by factional struggles, which is reflected in the data. The Independence Party and the Social Democrats, on the other hand, are the parties which adopted the most inclusive system of primaries and a superficial glance might seem to lend support to $\mathrm{H} 3$ concerning the effects of the primaries. The problem is that the last column indicates that party cohesion was already declining, especially in the Independence Party, before the primaries were adopted. 
There is no reason to suggest, of course, that open primaries must be the only reason why cohesion might weaken in a parliamentary party group. Thus, the decline of cohesion in the Independence Party during the 1960s might have occurred for some other reason during the 1970s. The problem is, however, that the primaries help us very little in making sense of the development of party cohesion in the Independence Party, shown in graph 2.

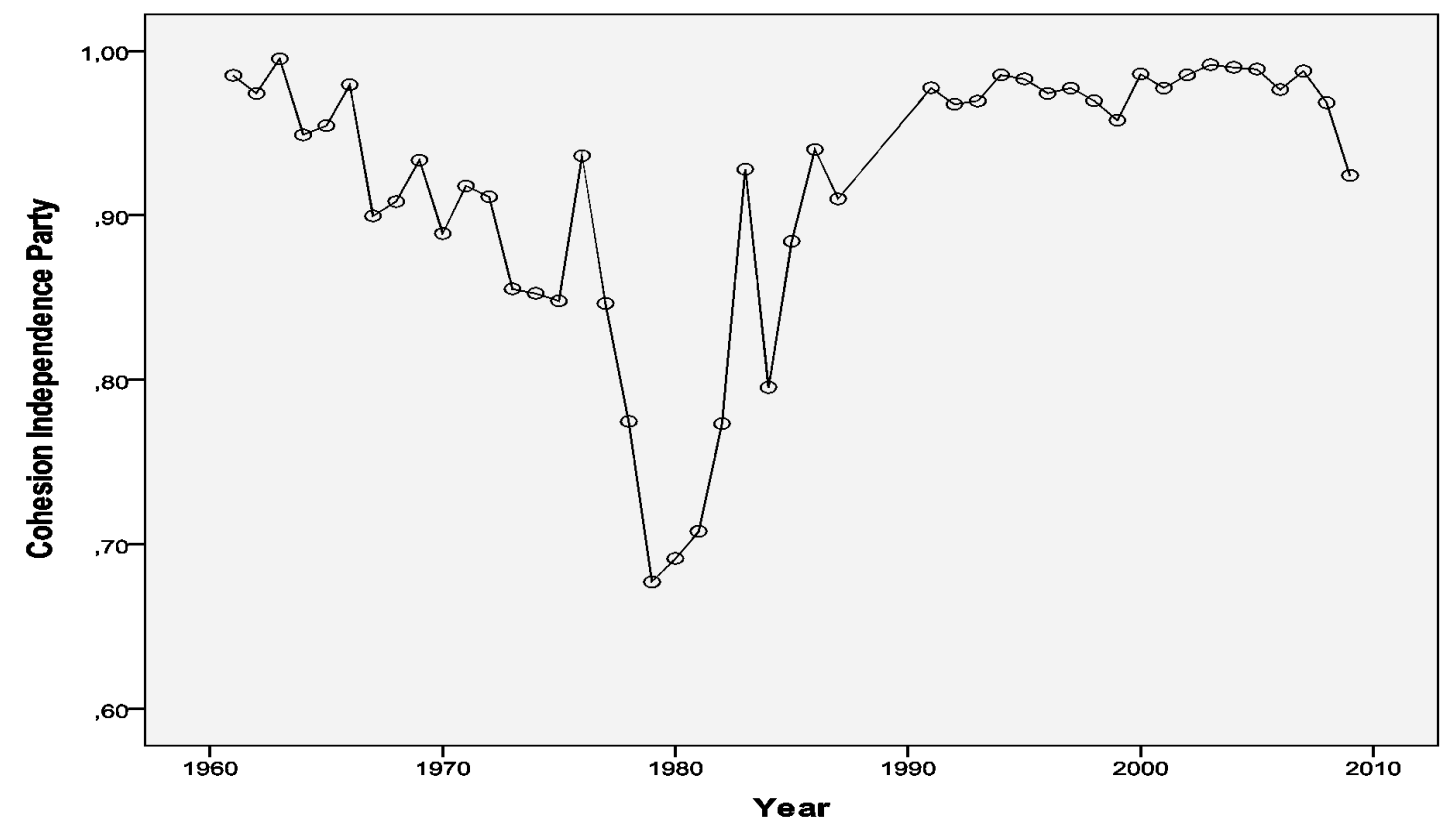

Note: Graph 2 is based on roll calls in 1961-87 and all voting where disagreement occurred 19912010; data for 1988-90 are missing.

Graph 2. Cohesion in the Indepdendence Party 1961-2010

The decline in party cohesion actually started well before the introduction of the primaries, and lack of cohesion may thus be an important reason why the primaries were introduced in the first place, rather than a consequence. A split in the party in the years around 1980 affected party cohesion significantly and it is fair to say that a decentralized and inclusive system of nominations did not make the task of the leadership at the time any easier. Despite the primaries, however, cohesion increased during the 1980s, and during the 1990s the party obtained a level of internal cohesion second to no other party in Iceland. As in some of the other parties, however, the economic crash in 2008 left its mark on the Independence Party.

\subsection{Parliamentary government (H4)}

According to $\mathrm{H} 4$, parliamentary government should lead to a high degree of party cohesion in Iceland. We have already found that party cohesion - despite open primaries - is high in Iceland, comparable to that prevailing in neighbouring North European states. Research indicates lower cohesion in separated, or presidential, than in parliamentary systems (Owens 2006; Hurley and Wilson 1989). Moreover, Carey (2007) shows that in parliamentary systems, governing parties are more unified than 
opposition parties, while in presidential systems, governing parties "are less unified overall than their counterparts under parliamentarism, win at lower rates, and when they lose they do so more frequently due to internal disunity" (p. 105).

Table 9. Party cohesion in government and opposition: Final votes on bills and disagreement issues 1991-2010

$\begin{array}{lcccc} & \begin{array}{c}\text { Final votes } \\ \text { on bills } \\ \text { Government }\end{array} & \text { Opposition } & \text { Disagreement } \\ & \text { issues } \\ \text { Independence Party (N) } & 99.11 & 96.06 & 97.85 & 92.42 \\ & (18) & (1) & (18) & (1) \\ \text { Left Greens* (N) } & 98.66 & 95.35 & 97.41 & 89.45 \\ & (1) & (18) & (1) & (18) \\ \text { Progressive Party (N) } & 99.40 & 95.27 & 98.53 & 91.54 \\ & (12) & (7) & (12) & (7) \\ \text { Social Democrats** (N) } & 99.35 & 96.33 & 97.87 & 90.62 \\ & (7) & (12) & (7) & (12) \\ \text { Weighted average } & 99.3 & 95.75 & 98.06 & 90.28 \\ \text { Note: Only parties which have been in government at least once in the period are covered. } \\ \text { *People's Alliance 1991-1998 } \\ \text { **Social Democratic Party 1991-1998 }\end{array}$

Table 9 indicates that party cohesion is greater among parliamentary party groups when they are in government than when in opposition. This applies to all parties, irrespective of whether final votes on all bills are considered or only bills where disagreement was present. The difference is particularly marked, however, with regard to disagreement issues, which is probably a more accurate indicator of cohesion. In the case of disagreement issues, the weighted average cohesion of government parties is $98 \%$, while for opposition parties it is $90 \%$. This result supports $\mathrm{H} 4$.

\subsection{Agenda control (H5)}

According to $\mathrm{H} 5$, control by governments of the parliamentary agenda should favour cohesion in the governing parties but have a harmful effect on cohesion in the opposition parties. We attempt to test this hypothesis by comparing final votes on bills to votes on amendments to bills. As mentioned above, the governing majority is firmly in control of determining which bills come to a vote in the Althingi, whereas any member can propose amendments to bills. 
Table 10. Party cohesion in government and opposition: Final votes and amendments (disagreement issues only) 1991-2010

Government

Final votes

Independence party $(\mathrm{N})$

97.85

97.41

Progressive Party (N)

98.53

Social Democrats** $(\mathrm{N})$

97.87
Amendments 97.74

98.38
Opposition

Final votes Amendments

92.42

89.54

91.54

(7)

90.62

90.33
95.59

93.34

Weighted average

98.06

98.19

Note: Only parties which have been in government at least once in the period are covered.

*People's Alliance 1991-98

**Social Democratic Party 1991-98

The effects of agenda control, as shown in Table 10, are not strong. Cohesion in government parties is about the same in votes on amendments as in final votes on bills. Cohesion in opposition parties, on the other hand, is slightly higher when they vote on amendments than in final votes on bills. This means that opposition parties on the whole do better at maintaining cohesion when they are free to make proposals than when they are confronted with government bills. Amendments are proposed both by government and opposition, and we have no means of controlling for how this affects voting by the opposition, but it seems likely that opposition parties are more united on their own proposed amendments than on government ones. Nonetheless, Table 10 lends only weak support for the hypothesized relationship between agenda control and party cohesion.

\section{Discussion}

Two institutional theories claim to account for party cohesion: on the one hand, a theory claiming that the system of nominations in place determines the degree of party cohesion and on the other, a theory which maintains that the structure of the executive is a decisive influence. In this article we have studied extensive data on party cohesion in Iceland, dating back to 1961, which has not been explored before. The data allows us to draw fairly clear conclusions with regard to the two institutional theories.

Nomination theory maintains that decentralized and inclusive nominations reduce party cohesion. According to this, Iceland, having used decentralized nominations from the beginning of the period under study and inclusive ones since the beginning of the 1970s, should be expected to display low party cohesion. Our tests, however, indicate that the level of party cohesion is much higher, in international comparison, than is compatible with the theory. It is at a level similar to that in the other Nordic 
countries, which use a much less inclusive system of nominations, and not markedly lower than in the British Isles, where nominations are more centralized. Moreover, nomination theory fails to predict correctly the pattern of party cohesion between parties and is unhelpful in accounting for its development over time.

Our ability to test theories based on the structure of the executive is limited by the fact that Iceland has had parliamentary government since 1904. However, the level of party cohesion is more similar to that found in parliamentary systems than the level in presidential systems. Moreover, we found clear evidence of the causal mechanism of greater pressure on governmental parties than opposition ones - although cohesion in the opposition parties is also relatively high. As pointed out, however, the wish to be seen to have government capacity also affects the opposition in parliamentary systems. Weak evidence was found of the effects of government agenda control on party cohesion.

Looking at the development of party cohesion over the whole period from 19612010 , it seems clear that at each point in time there are more factors at work than the simple facts of parliamentary government, access to government and agenda control. These include such factors as the strength of party leaders and strife between individual leaders and factions. Calculating the mean party cohesion for the four major parties in 1961-2010 we obtain the pattern in Graph 3.

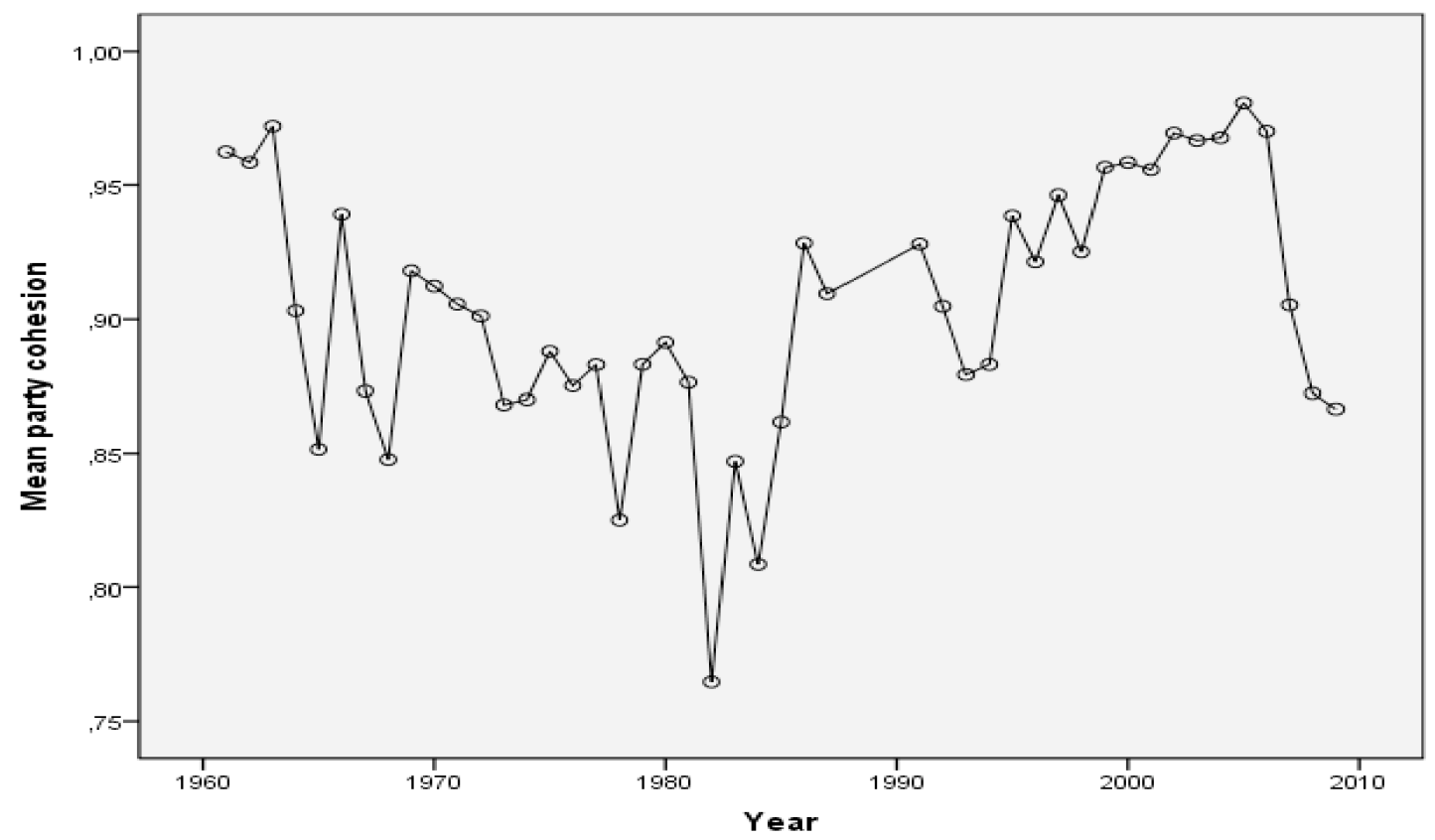

Note: Including Independence Party, Left Greens/People's Alliance, Progressive Party and Social Democrats. Based on roll-calls 1961-88 and final votes with disagreement in 1991-2010. Data for 1988-91 are missing.

Graph 3. Mean party cohesion in major parties 1961-2010

Many of the twists and turns seem to have roots which are explicable in terms of individual contexts. The graph reflects growing resistance against party discipline in the 1960s which culminated in shake-up in the party system in the late 1970s and 1980s 
(although data for 1988-91 is missing). This included major swings in elections from 1978, party splits (in the Independence Party and Social Democrats) and the emergence of three additional parties during the 1980s (the Women's Alliance, Social Democratic Union and Citizens' Party). During the 1990s, however, the party leaders seem to have regained control in the parties, although we have to bear in mind that the data from 1991 is, strictly speaking, not fully comparable to that used for the earlier period. A factor which contributed to this development is very likely the increasing role played by the party leaders since the late 1980s or early 1990s in selecting individuals to serve as ministers and in other positions of influence in the parties (Kristinsson 2009). The ability to reward and punish has brought greater cohesion to the parliamentary groups in recent decades. Graph 3, however, also shows how party cohesion can be affected by individual events, such as the economic crash in Iceland in 2008, followed by the "pots and pans revolution". The legitimacy of party organizations and party discipline, which had been in focus since the 1960s, received a severe blow, as has become apparent, for example, in a drastic decline in public confidence in politicians (Capacent Iceland, 2011).

The challenge is to explain why party cohesion came under pressure during the 1960s, recovered during the 1990s and declined again after the crash in 2008. This subject can only be touched upon very briefly, and the following comments may be regarded as suggestions for future research rather than conclusions of the present study. The Icelandic parties were originally organized as clientelist organizations, distributing values through patronage networks (Kristinsson 1996; Indridason 2005). Access to patronage gave the party leadership considerable leverage in dealing with parliament. The embryo of a patronage theory of party cohesion was suggested by David Hume (1758) when defending the crown usage of patronage to control parliament: "[W]e may call it by the invidious appellations of corruption and dependence; but some degree and some kind of it are inseparable from the very nature of the constitution, and necessary to the preservation of our mixed government." Without the judicious use of patronage, he maintained, the government would not be able to maintain the control over parliament that was necessary to provide leadership.

Clientelism in Iceland, in a similar manner, strengthened the party leaders when dealing with their parliamentary party groups. Hence, the decline of clientelism, starting in the 1960s (Kristinsson 2001), posed a problem of leadership in the parties. This may have been aggravated by the primaries to some extent, but the introduction of the primaries does not account for the overall pattern and development of party cohesion. During the 1990s, the party leaders mastered the use of patronage in a much narrower sense of the word, confining it to a greater extent than before to promotions in the parliamentary groups and strategically important positions in the public sector (Kristinsson, forthcoming). This appears to have increased cohesion in the parliamentary groups until the crash in 2008. A drop in cohesion after the crash seems to reflect increasing distrust in politicians and a suspicion that during the economic expansion, critical voices were hushed and public discourse dominated by a small political elite (Rannsóknanefnd Alpingis, 2010, vol. 8). 


\section{Notes}

The author has benefited from useful comment by two reviewers and discussions in the departmental seminar in political science at the University of Iceland. Above all, however, Sigrún H. Jónsdóttir, who was research assistant in this project, made an invaluable contribution.

2 The formula can thus be put: Cohesion $=\%$ majority votes $-\%$ minority votes

I.e.: Cohesion $=\%$ majority votes $-(\%$ minority votes $+\%$ abstentions $)$

In this case we calculate:

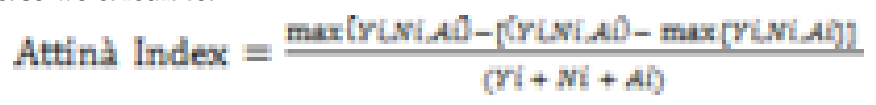

(formulation according to Hix 2005) where (in a vote $i$ ) $\mathrm{Y}$ is the number of yes votes, $\mathrm{N}$ the number of no votes and $\mathrm{A}$ the number of abstentions. (i.e. present but do not vote).

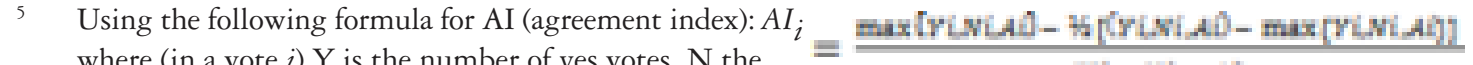
where (in a vote $i) \mathrm{Y}$ is the number of yes votes, $\mathrm{N}$ the $\mathrm{Wi}+\mathbf{N i}+\mathbf{A l}]$ number of no votes and $\mathrm{A}$ the number of abstentions. (i.e. present but do not vote).

6 The correlations are based on means for each party with more than three members per year in the period 1991-2010 in final voting on bills $(\mathrm{N}=83)$.

7 The basic idea here is influenced by the notion of party vote, introduced by Lowell (1902) in his analysis of British and American parties which refers to voting where a large proportion (e.g. majority, or in Lowell's version over 90\%) of one party votes against a large proportion of the other. The frequency of party votes may be taken to indicate the importance of party in parliament which takes note of the fact that some issues pass without any controversy at all. Unfortunately the notion of party vote assumes a two-party context, which is realistic in only a minority of party systems.

8 According to Saalfeld $(1995,539)$ the average number of roll-calls in the Althingi per year in 1986-91 was 51.

9 The formula used by Jensen is actually a modified version of the Rice index formula which empirically - at least in the Icelandic case - gives almost identical results to Attinà agreement index.

10 Parties with three members or less were excluded in these calculations on account of unstable results.

11 Based on information from party headquarters.

\section{References}

Annual reports of the Althingi (Ársskýrslur Alpingis), relevant years. Reykjavík: Alpingi.

Arter, D. 2000. "From a 'peasant parliament' to a 'professional parliament'? Change in the Icelandic Althingi”, The Journal of Legislative Studies, 6:2, 45-66.

Attinà, F. 1990. "The voting behaviour of the European Parliament members and the problem of Europarties", European Journal of Political Research, 18, 557-79.

Beyme, K. 2000. Parliamentary democracy. Houndmills: Macmillan.

Bille, L. 2001. "Democratizing a democratic procedure: Myth or reality?" Party Politics, 7:3, 363-380.

Bowler, S., Farrell, D., \& Katz, R. (eds.) 1999. Party discipline and parliamentary government. Columbus: Ohio State University Press.

Bowler, S., Farrell, D. \& Katz, R. 1999. "Party cohesion, party discipline, and parliaments”. Bowler et al. (eds.) Party discipline and parliamentary government. Columbus: Ohio State University Press. 3-22

Bowler, S. 2000. "Parties in legislatures: Two competing explanations". In Dalton, R. \& Wattenberg, M. (eds.) Parties without partisans (Oxford: Oxford University Press), pp. 157-179.

Capacent Iceland 2011. Pjółarpúlsinn, http://capacent.is/frettir-ogfrodleikur/thjodarpulsinn/thjodarpulsinn/2011/02/25/Traust-til-margra-stofnana-a-uppleid/ (viewed Sept. 1, 2011).

Carey, J. 2007. "Competing principals, political institutions and party unity in legislative voting". American Journal of Political Science, 51:1, 92-107.

Cox, G. 1987. The efficient secret. The cabinet and the development of political parties in Victorian England. (Cambridge: Cambridge University Press).

Crewe, I. \& Särlvik B. 1983. Decade of dealignment (Cambridge: Cambridge University Press).

Davidson-Schmich, L. 2006. "The Origins of Party Discipline”, German Politics and Society, 24:2, 23-43

Depauw, S. \& Martin, S. 2009. "Legislative Party Discipline and Cohesion in Comparative Perspective" in Daniela Giannetti and Kenneth Benoit (eds.). Intra-Party Politics and Coalition Government, (Oxon: Routledge) 103-120. 
Döring, H. 1995. "Time as a scarce resource: Government control of the agenda”. Döring, H. (ed.) Parliaments and majority rule in Western Europe (Frankfurt: Campus Verlag) 223-247.

Gallagher, M., Laver, M. \& Mair, P. 2006. Representative Government in Modern Europe (Boston: McGraw-Hill).

Hazan, R.(ed.) 2006. Cohesion and discipline in legislatures. London: Routledge.

Hix, S., Noury, A. \& Roland, G. 2005. "Power to the parties: Cohesion and competition in the European Parliament, 1979-2001”, B.J.Pol.S. 35, 209-234.

Hug, S. 2009. "Selection effects in roll call votes", B.J.Pol.S. 40, 225-235.

Hume, D. (1758). "Of the Independency of Parliament" in Essays, Moral, Political and Literary. Electronic text available at http://www.davidhume.org/texts/emp\#Mil42

Hurley, P. \& Wilson, R. 1989, Partisan voting patterns in the U.S. Senate 1877-1986. Legislative Studies Quarterly, $14: 2,225-250$

Indridason, I. 2005. A theory of coalitions and clientelism: Coalition politics in Iceland 1945-2000”, European Journal of Political Research 44: 439-464.

Jensen, T. 2000. "Party cohesion". Esaiasson, P. \& Heidar, K. (eds.) Beyond Westminster and congress: The Nordic experience. Columbus: Ohio State University Press. 210-236.

Kam, C. 2009. Party discipline and parliamentary politics. Cambridge: Cambridge University Press.

Kristinsson, G.H., forthcoming. "Rewards and control appointments in Iceland". Kopecký, Petr, Peter Mair and Maria Spirova (eds.) Party Patronage and Party Government in European Democracies. Oxford: Oxford University Press.

Kristinsson, G. H. 2010. "Fjölmennustu flokkar heims. Meðlimaskipulag íslenskra stjórnmálaflokka”, Stjórnmál og stjórnsýsla, 6:2, 123-150.

Kristinsson, G.H. 2009. "More safe than sound? Cabinet ministers in Iceland”. Dowding, K. \& Dumont, P. (eds.) The selection of ministers in Europe. Hiring and firing. London: Routledge. 194-203.

Kristinsson, G.H. 2001. "Clientelism in a cold climate: the case of Iceland". Piattoni, S. (ed.) Clientelism, interests and democratic representation. Cambridge: Cambridge University Press.

Kristinsson, G.H. 1996. "Parties, states and patronage", West European Politics, 19:3, 433-457.

Kristjánsson, S. 2003. "Iceland: a parliamentary democracy with a semi-presidential constitution”. Ström K., Müller, W. \& Bergman, T. (eds.) Delegation and accountability in parliamentary democracies. Oxford: Oxford University Press. 399-417.

Kristjánsson, S. 1994. Frá flokksrceði til persónustjórnmála. Reykjavík: Félagsvísindastofnun.

Loewenberg, G. \& Patterson, S. 1979. Comparing legislatures. Boston: Little, Brown \& Co.

Lowell, A. 1902. "The influence of party upon legislation in England and America", Annual Report of the American Historical Association for the year 1901, vol. 1. Washington: U.S. Government Printing Office. 319-542.

Mattson, I. 1995. "Private members' initiative and amendments". In Döring, H. (ed.) Parliaments and majority rule in Western Europe (Frankfurt: Campus Verlag), 448-487.

Magnússon, P. 2011. "Sampætting valdpáttanna og hlutverk Alpingis” in Helgadóttir, R., Kjartansson, H. \& Magnússon, P. (eds.) Pingræði á Íslandi. Samtíð og saga. Reykjavík: Forlagið.

Narud, H. 2008. Bak lukkede dører? Eller i apne rom? Demokratiske normer for politisk rekuttering. Oslo: Civita.

Nielsen, P. 2007. Ett decennium med personval - erfarenheter och utfall. Rapport till Grundlagsutredningen, version 2007-05-11

Owens, J. 2006. Explaining Party Cohesion and Discipline in Democratic Legislatures: Purposiveness and Contexts. Hazan, R. Eed) Cohesion and discipline in legislatures, London: Routledge. 12-40.

Ozbudun, E. 1970. Party cohesion in Western Democracies. Beverly Hills: Sage.

Panebianco, A. 1988. Political parties: Organization E power (Cambridge: Cambridge University Press).

Rahat, G. 2007. "Determinants of party cohesion: Evidence from the case of the Israeli parliament", Parliamentary Affairs, 60:2, 279-296.

Rahat, G. \& Hazan, R. 2001. "Candidate selection methods. An analytical framework", Party Politics, 7:3, 297-322.

Rannsóknarnefnd Alpingis 2010. Aðdragandi og orsakir falls íslensku bankanna 2008 og tengdir atburđir. Reykjavík: Rannsóknarnefnd Alpingis. Vol. 8.

Rice, S. 1925. "The Behavior of Legislative Groups: A Method of Measurement", Political Science Quarterly, 40:1, $60-72$

Saalfeld, T. "On dogs and whips: Recorded votes". Döring, H. (ed.) Parliaments and majority rule in Western Europe (Frankfurt: Campus Verlag) 528-565.

Sartori, G. 1994. Comparative constitutional engineering. New York: New York University Press.

Sieberer, U. 2006. Party unity in parliamentary democracies: A comparative analysis. The Journal of Legislative Studies, 12:2, 150-178.

Whiteley, P. 2011. "Is the party over? The decline of party activism and membership across the democratic world". Party Politics 17:1, 21-44. 